\title{
Spatio-Temporal Study of Toxic and Harmful Planktonic Taxa at Two Oceanic Sites Mehdia and Moulay Bousselham, Rabat Sale Kenitra Region, Morocco, between 2017 and 2018
}

\author{
A. Hal Aberrhaman, B. Bouhaddioui, L. A. Lrhorfi, R. Bengueddour \\ Biology Department, Laboratory Biochemistry, Biotechnology, Health and Environment, Faculty of Science, Ibn Tofail University, \\ Kenitra, Morocco \\ Email: azza-20111@hotmail.fr,dr_bouchra2010@yahoo.fr, alrhorfi_com@yahoo.fr, rachidbengueddour@yahoo.fr
}

How to cite this paper: Aberrhaman, A.H., Bouhaddioui, B., Lrhorfi, L.A. and Bengueddour, R. (2020) Spatio-Temporal Study of Toxic and Harmful Planktonic Taxa at Two Oceanic Sites Mehdia and Moulay Bousselham, Rabat Sale Kenitra Region, Morocco, between 2017 and 2018. Open Journal of Marine Science, 10, 41-51. https://doi.org/10.4236/ojms.2020.102004

Received: December 22, 2019

Accepted: March 29, 2020

Published: April 2, 2020

Copyright $\odot 2020$ by author(s) and Scientific Research Publishing Inc. This work is licensed under the Creative Commons Attribution International License (CC BY 4.0).

http://creativecommons.org/licenses/by/4.0/

\begin{abstract}
Phytoplankton is all cyanobacteria and microalgae (microscopic plants) present in surface water that may be carried by water currents. The study was conducted at two oceanic sites Mehdia and Moulay Bousselham, Rabat sale Kenitra region, Morocco, between 2017 and 2018. The objective of this study is to compare the spatiotemporal evolution of certain toxic planktonic species between the two sites. The planktonic species identified all have toxic potency but to varying degrees such as Alexandrium, Dinophysis, Gymnodinum, Pseudonitzschia and Proocentrum. The comparison of the abundance of these taxa in the two sites confirms that the Moulay Bousselham site is characterized by the presence of the most toxic planktonic species represented mainly by Pseudonitzschia in contrast the Mehdia site experienced an abundance of the Proocentrum kind. This situation requires a more detailed study of the essential causes of the proliferation of these species.
\end{abstract}

\section{Keywords}

Phytoplankton, Surface Water, Toxic Power, Spatiotemporal Evolution, Mehdia, Moulay Bousselham

\section{Introduction}

Phytoplankton is all the cyanobacteria and microalgae (microscopic plants) present in surface water that can be carried away by water currents [1] [2]. They are defined as unicellular or multicellular organisms, either eukaryotes or prokaryotes [3]. Microalgae occupy most ecological niches, mainly aquatic envi- 
ronments; they live in salt marshes, in acidic or strongly alkaline environments [4]. According to Greenway and Munns (1980); Dabbadie (1992); Netondo et al. (2004); Perrine et al. (2012) [5] [6] [7] [8], the factors favoring a better microalgal production are the illumination, the temperature whose optimum is $18^{\circ} \mathrm{C}$ to $24^{\circ} \mathrm{C}$ affording to the species. The $\mathrm{Ph}$ must be between 8.2 and 8.7, nitrogen and phosphorus and other elements. Phytoplankton occupies the place of the first link in the food chain [9], it is the basis of ecosystems in marine environments [10]. The distribution, abundance, production and biodiversity of different species or groups of plankton are likely to be deeply affected by climatic changes and the physical and chemical properties of oceans [1]. Of the many species that make up phytoplankton, some produce toxins called phycotoxins. They belong mainly to the Dinophyceae class [11].

In Morocco, there are 84 listed wetlands according to the 1997 Protected Areas Study. Another study reports about 300 sites covering an area of 400,000 ha. Morocco's Gharb is rich in wetlands such as the Mehdia area and Moulay Bousselham, which are considered among the most populated areas by planktonic species.

The objective of this study is to compare the spatiotemporal evolution of certain toxic planktonic species between two wet sites Mehdia and Moulay Bousselham.

\section{Material and Methods}

\subsection{Description of the Study Site}

The samples were taken from two ocean sites, the Mehdia and Moulay Bousselham in the Rabat-Sale-Kenitra region. The first site is a picturesque coastal town near the Kenitra city, $30 \mathrm{~km}$ northeast of the capital Rabat. The average annual temperature is $18.6^{\circ} \mathrm{C}$ and the average rainfall is $283 \mathrm{~mm}$. The second site is known for heavy rainfall in winter than in summer. The average annual temperature is $18.1^{\circ} \mathrm{C}$, and the average annual precipitation is $622 \mathrm{~mm}$.

\subsection{Identification of Species}

For the identification of phytoplankton, a volume of $500 \mathrm{ml}$ of seawater is collected at $0.5 \mathrm{~m}$ depth using opaque glass bottles. The sample is then fixed with $2.5 \mathrm{ml}$ of alkaline lugol and placed in a cool box protected from light. In the laboratory, samples are recorded and stored in the dark at $4^{\circ} \mathrm{C}$.

After vigorous stirring, the samples are decanted for 24 hours and then subjected to observation under optical microscope morpho-anatomic characters (shape, size and color) representing the identification keys retained by Gregoire et al., 1978; Bourrelly, 1985 [12] [13]. The cells are then counted per liter per vat.

\subsection{Statistical Analyzes}

The collected data are entered on an Excel support, the exploitation is carried out on a statistical processing software. The selected analyzes in this sense are 
significance tests such as single-point analysis of variance, correlations, principal component analysis. The results are generally expressed as relative frequencies and/or means \pm standard deviation.

\section{Results and Discussion}

\subsection{Study of the Density Variation in the Two Sampling Sites}

Table 1 presents the results of the distribution of planktonic cells according to the years of sampling and according to the sampling sites. The results are expressed in mean and standard deviation. The comparison test and the student test. An Asterix marks significant differences.

* In a first step, we compared the average densities between the two sites by year of sampling. The results obtained show that, in general, the abundance in 2017, except for the Proocentrum taxon where the density in the Mehdia station exceeds that of Moulay Bousselham, the other planktonic species have been highly represented in the Moulay Bousselham station. The student test confirmed the effect of the site only for the Dinophysis taxon with a $t=3.41$ and $p<$ 0.003 .

${ }^{\star}$ In a second time, and in 2018, the average density of plankton in the Moulay Bousselham site exceeds that of the Mehdia site, with the exception of Gymnodinum and Pseudonitzscia where it is the opposite. The student test shows a significant difference between the two stations for the Alexandrium taxon.

The planktonic species identified all have toxic potency but to varying degrees. Because of this, the abundance of these species in the Moulay Bousselham site makes the environment really too incriminated.

\subsection{Study of the Spatio-Temporal Variation of Toxic Taxa}

\subsubsection{Variation of the Genus Alexandrium}

Alexandrium is a nucleated unicellular living organism belonging to the Dinophyte group. Several Alexandrium species (Gonyaulax or Protogonyaulax) produce paralytic toxins, particularly in the Pacific Northwest, North East Coast of North America and Northern Europe. While in Morocco, paralytic poisoning is due to the efflorescence of Gymnodinum catenatum [14].

The distribution of Alexandrium densities according to years of sampling shows a very remarkable difference between 2017 and 2018, these averages are respectively $217.83 \pm 470.19$ cells/liter $(\operatorname{Min}=0, \operatorname{Max}=1990)$ and $89.55 \pm 74.03$ cells/liter ( $\operatorname{Min}=0, \operatorname{Max}=200)$. This difference in density is largely felt between the two sampling sites Mehdia and Moulay Bousselham, with mean values of 61.39 \pm 7.98 cells/liter $(\mathrm{Min}=0, \mathrm{Max}=290)$ and $251.57 \pm 46.17$ respectively. Cells/liter ( Min $=0, \operatorname{Max}=1990)$, this difference is significant between the means of the two sampling sites (Fisher $=3.68, \mathrm{p}<0.048$ ). Analysis of variance did not show any interaction between the year factor and the sampling site factor (Fisher $=1.06, \mathrm{p}<$ 0.31 ). Figure 1 shows the mean points of the monthly density in the two stations. The results show an abundance of the Alexandrium species in Moulay Bousselham station. Indeed, two maximum peaks characterize the two sites, 
Table 1. Presentation of plankton species according to years and sampling sites.

\begin{tabular}{|c|c|c|c|c|c|c|}
\hline \multirow[t]{2}{*}{ species } & \multirow[t]{2}{*}{ Site } & \multicolumn{2}{|c|}{ Year of sampling: 2017} & \multicolumn{2}{|c|}{ Year of sampling: 2018} & \multirow[t]{2}{*}{ Significant } \\
\hline & & Mean (cells/liter) & Standard deviation & Mean (cells/liter) & Standard deviation & \\
\hline \multirow{2}{*}{ Alexandrium } & Site I & 74.33 & 95.51 & 47.27 & 50.81 & NS \\
\hline & Site II & 361.33 & 638.92 & 131.82 & 70.68 & NS \\
\hline signification & & $\mathrm{t}=1.54 ; \mathrm{p}<0.14$ & & $\mathrm{t}=3.54 ; \mathrm{p}<0.004^{\star *}$ & & \\
\hline \multirow{2}{*}{ Dinophysis } & Site I & 41.67 & 90.03 & 122.73 & 375.08 & NS \\
\hline & Site II & 371.67 & 322.77 & 1036.36 & 2198.76 & NS \\
\hline signification & & $\mathrm{t}=3.41 ; \mathrm{p}<0.003^{* *}$ & & $\mathrm{t}=1.36 ; \mathrm{p}<0.194$ & & \\
\hline \multirow{2}{*}{ Gymnodinum } & Site I & 216.67 & 257.91 & 877.27 & 1680.98 & NS \\
\hline & Site II & 466.67 & 502.87 & 172.73 & 134.84 & $\mathrm{t}=1.87 ; \mathrm{p}<0.037^{\star *}$ \\
\hline signification & & $\mathrm{t}=1.3 ; \mathrm{p}<0.14$ & & $\mathrm{t}=1.39 ; \mathrm{p}<0.19$ & & \\
\hline \multirow{2}{*}{ Pseudonitzschia } & Site I & 2741.67 & 4792.13 & 4727.27 & 5921.84 & NS \\
\hline & Site II & $10,616.67$ & $18,005.04$ & 3259.09 & 2972.78 & NS \\
\hline signification & & $\mathrm{t}=1.46 ; \mathrm{p}<0.16$ & & $\mathrm{t}=0.73 ; \mathrm{p}<0.47$ & & \\
\hline \multirow{2}{*}{ Proocentrum } & Site I & 6166.67 & 9369.52 & 3000.00 & 1788.85 & NS \\
\hline & Site II & 4250.00 & 4025.49 & 3727.27 & 1489.36 & NS \\
\hline signification & & $\mathrm{t}=0.65 ; \mathrm{p}<0.5$ & & $\mathrm{t}=1.04 ; \mathrm{p}<0.31$ & & \\
\hline
\end{tabular}

NS: no significant; ${ }^{* *}$ : significant at $5 \%$.

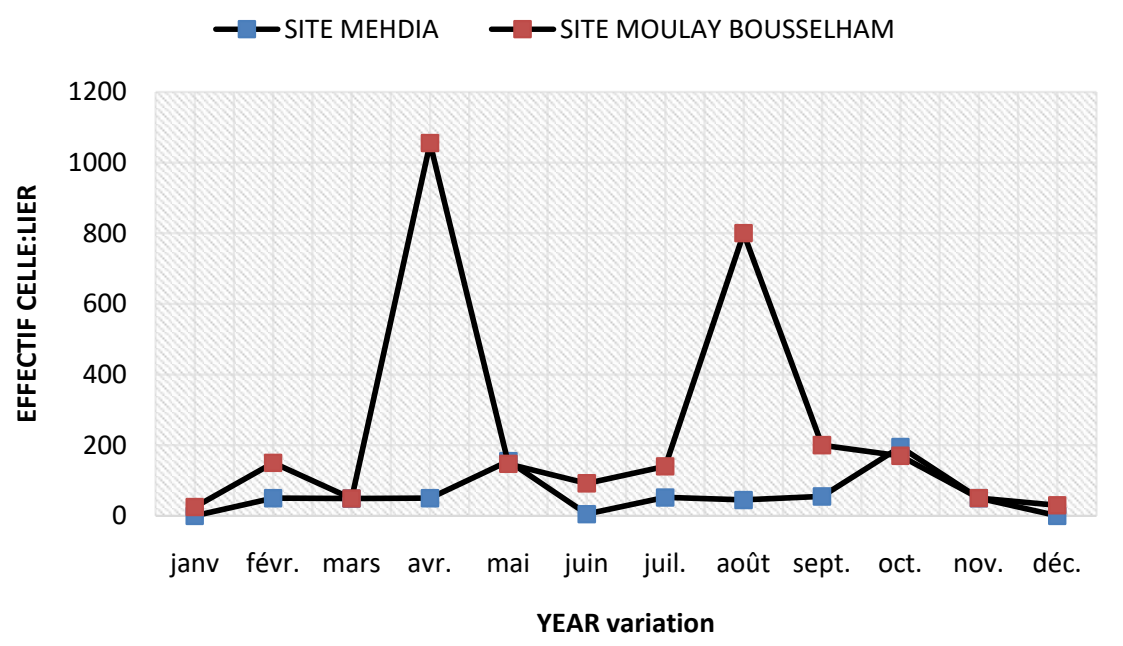

Figure 1. Number of cells counted per month at both sites at Alexandrium.

- For the Moulay Bousselham station, average densities are highest during the months of April and August, which correspond to the spring and summer seasons, with respectively more than 1000 cells/liter and more than 800 cells/liter.

- For the Mehdia site, the monthly distribution shows that the cell density peaks are recorded during the month of May (more than 180 cells/liter) and the month of October (more than 200 cells/liter) which correspond to the 
seasons spring and autumn.

\subsubsection{Variation of the Genus Dinophysis}

The Dinophysis genus belongs to the class of dinophyceae. It includes many Dinophysis species, most of which are toxic.

The annual distribution of the average density of Dinophysis shows that in 2017, the average is $206.67 \pm 58.49$ cells/liter ( $\mathrm{Min}=0, \mathrm{Max}=900)$ and in 2018 it reaches $579.55 \pm 342.97$ cells/liter $(\mathrm{Min}=0, \mathrm{Max}=7500)$. Analysis of variance showed a significant sampling site effect on the distribution of this plankton species (Fisher $=3.50, \mathrm{P}<0.044$ ). Indeed, the average density in the Moulay Bousselham station $(689.57 \pm 320.66$ cells/liter) exceeds that of Mehdia (80.43 \pm 55.05 cells/liter). The analysis of variance did not show any interaction between the year factor and the sampling site factor (Fisher $=0.80, \mathrm{p}<0.37$ ). Figure 2 shows the mean points of the monthly density of the planktonic Dinophysis species at both stations. It appears that this species is very abundant in the Moulay Bousselham station. Indeed, two maximum peaks characterize the two sites:

- The monthly variation of the Dinophysis density in the Moulay Bousselham station has a peak exceeding 4000 cells/liter during the month of June, and to a lesser degree a second peak during the month of March (more than 170 cells/liter).

- For the Mehdia site, the monthly distribution shows that cell density peaks are recorded during the month of July (more than 500 cells/liter) and low during the other months of the year.

\subsubsection{Variation of the Species Gymnodinum}

The Gymnodinum sp., represent an important genus of the dinoflagellate protist group, the marine plankton without theca of the class Dinophyceae, order Gymnodinuales. It is a species of red tide forming chains and producing toxins.

The average density of the cells of this planktonic species per liter per year of sampling shows that this average is $341.67 \pm 83.93$ cells/liter during the year 2017, with a minimum of 0 cells/liter and a maximum of 1600 cell/liter, whereas for the year 2018, the average is $525.00 \pm 259.74$ cells/liter $(\mathrm{Min}=0$, Max $=$ 4500). Despite the difference in record between these two years, the Fisher test did not assert the direct effect of the year variation on density (Fisher $=0.48, \mathrm{p}<$ 0.49). On the other hand, the distribution of the number of planktonic cells per liter of water per sampling site shows that the Mehdia station has an average density of $532.61 \pm 249.48$ cells/liter $(\min =0, \max =4500)$, higher than that recorded at Moulay Bousselham $($ mean $=326.09 \pm 82.68$ cells, $\operatorname{Min}=0$, Max $=$ 1600). Given the large intra-station dispersion, the file test did not show a significant difference between the two stations (Fisher $=0.62, \mathrm{p}<0.44$ ). The analysis of variance shows that the year factor and the station factor interact significantly with each other (Fisher $=3.44, \mathrm{p}<0.047$ ), thus having an effect on the density of this plankton.

Figure 3 shows the mean points of the monthly density of the planktonic 


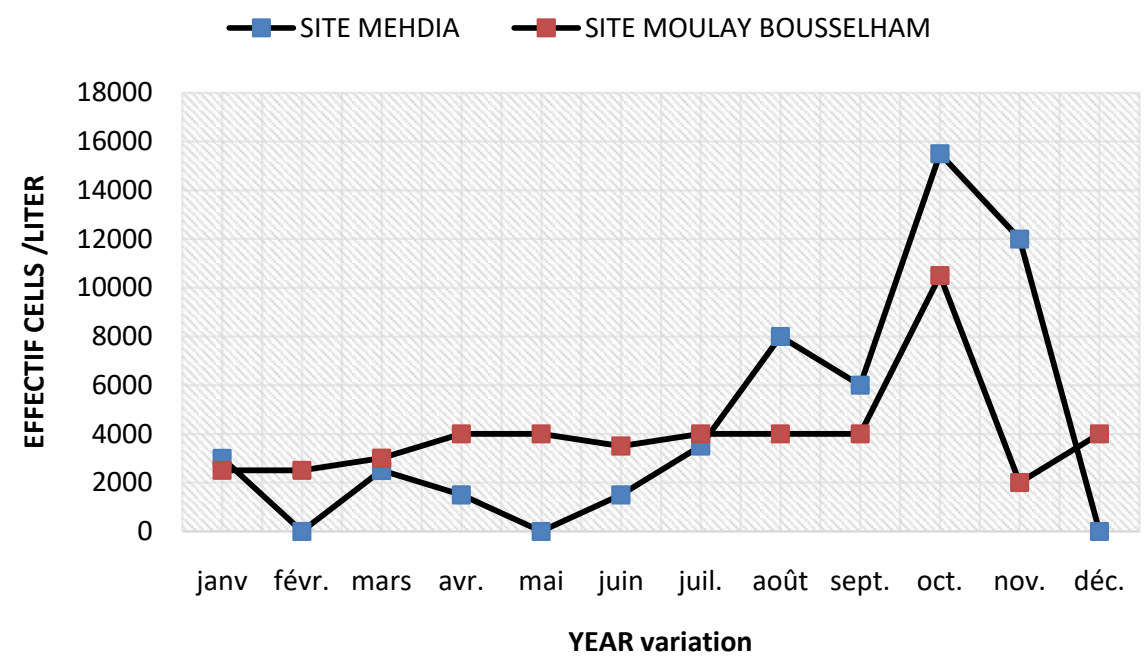

Figure 2. Number of cells counted per month in the two sites at Dinophysis.

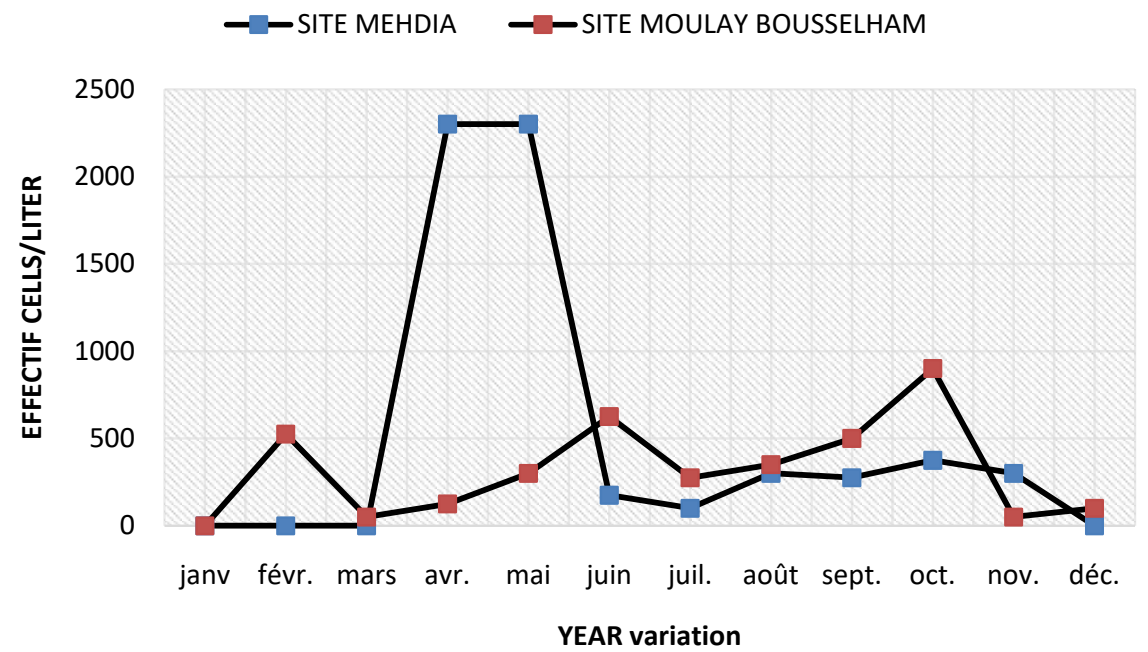

Figure 3. Number of cells counted per month at both sites at Gymnodinum.

Gymnodinum species at both stations. As a result, this taxon is very common in the Mehdia station, with two peaks in April and May; the density during these two months exceeds 2000 cells/liter. However, in the Moluay Bousselham station, there were three peaks in February (more than 500 cells/liter), in June (more than 600 cells/liter) and in October (more than 900 cells /liter).

\subsubsection{Variation of the Species Pseudonitzschia}

The micro-algae of the genus Pseudonitzschia are Diatoms of the family Bacillariaceae. Some species of this genus produce domoic acid, a neurotoxin responsible for food poisoning (ASP for Amnesic Shellfish Poisoning).

The mean densities of the Pseudonitzschia cells determined for the two years of study 2017 and 2018 are respectively $6679.17 \pm 2755.33$ cells/liter (Min $=0$, $\operatorname{Max}=65,000)$ and $3993.18 \pm 987.93$ cells/liter $(\operatorname{Min}=0, \operatorname{Max}=19,000)$. The Fisher test did not show any effect of the year variation on the distribution of the cell density despite the difference between the average densities during the years 
2017 and 2018, this is attributed to the great heterogeneity recorded in each group. The comparison of the mean Pseudonitzschia densities between the two sites, Mehdia and Moulay Bousselham, shows a great difference between these two stations, the corresponding averages recorded being $3691.30 \pm 1112.202$ $(\operatorname{Min}=0, \operatorname{Max}=19,000)$ in the Mehdia station and 7097.83 $\pm 2799.298(\operatorname{Min}=0$; $\operatorname{Max}=65,000)$ in the Moulay Bousselham station.

Figure 4 shows the mean points of the monthly density of the planktonic species Pseudonitzschia in both stations. It appears from this figure that this taxon is very common in Moulay Bousselham station, with a peak in July and the density reaches more than 32,000 cells/liter. However, the distribution of this monthly taxon in the Mehdia station fluctuates around a density of 5000 cells/liter, especially in February, April, August and October.

\subsubsection{Variation of the Proocentrum Species}

Proocentrum is a dinoflagellate in formation, forming an armor, marine, planktonic. It is a cosmopolitan species in cold temperate waters with tropical waters. It is generally considered harmless [15] [16] [17].

The evolution of this taxon between 2017 and 2018 shows a decrease in average density, the rate of decline reaches $35.48 \%$. The minimum number of cells determined is zero cells/liter and the maximum is displayed during the year 2017 , it is 28,000 cells/liter. Regarding the distribution of this taxon in the two sampling sites, we did not notice a large difference between these two sites. The file test did not show a significant difference (Fisher $=0.17, \mathrm{p}<0.61$ ), between the mean density at the Mehdia site is 4652.17 cells/liter and the average density at the Moulay Bousselham site is 4000.00 cells/liter.

The monthly distribution at both stations is shown in Figure 5. The distribution of the Proocentrum at the Mehdia site is marked by a maximum in October (more than 14,000 cells/liter) and second peak in August but that does not exceed 8000 cells/liter. However, the distribution in the Moulay Bousselham station, a maximum is recorded in October at a density of more than 10,000 cells/liter, for other months, the density fluctuates between 2000 and 4000 cells/liter.

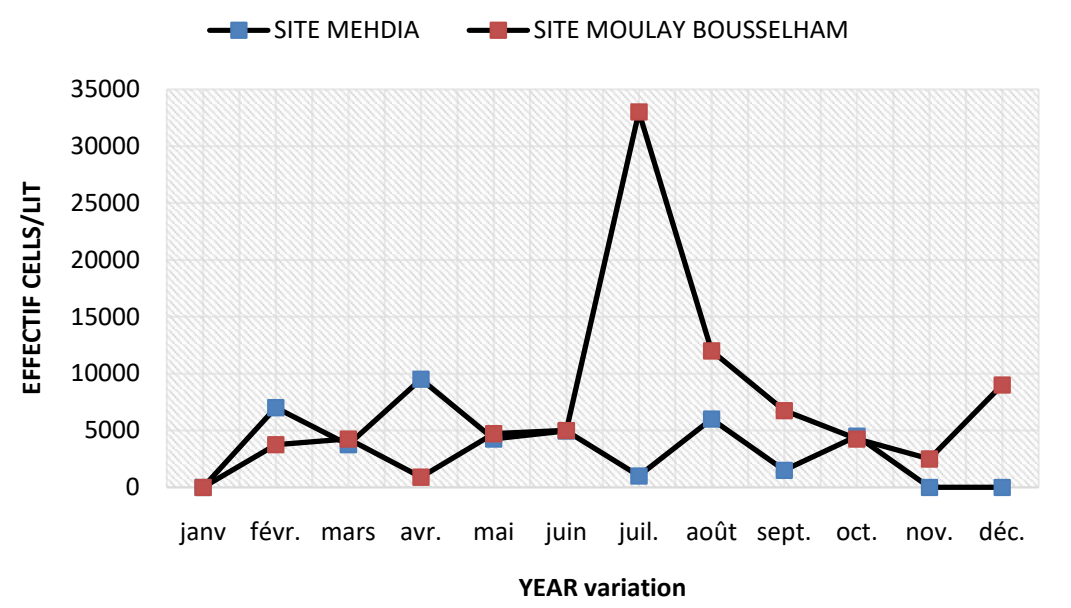

Figure 4. Number of cells counted per month in both sites at Pseudonitzschia. 


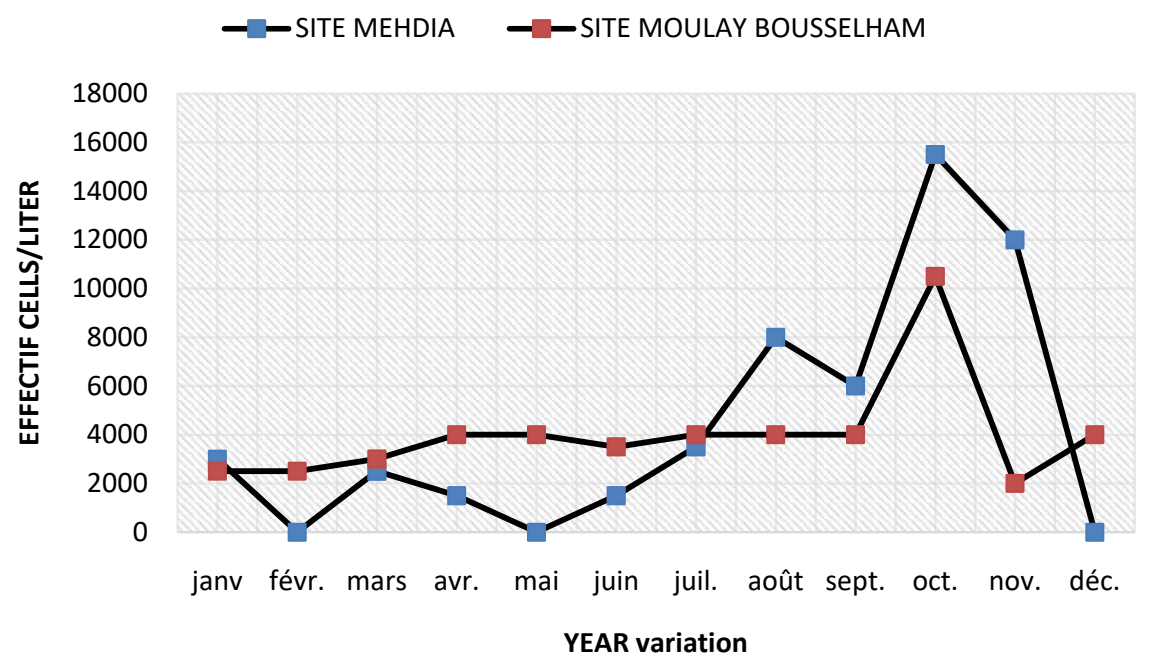

Figure 5. Number of cells counted per month in both sites at proocentrum.

\subsection{Global Analysis}

In this part, we used a joint analysis of the five toxic taxons according to the cell density, the site of the site and the month of sampling. The two figures below represent hierarchical classification dendrograms of the five species identified. Figure 6(a) shows the projection results of the toxic taxa identified in the Mehdia site. This analysis reveals three distinct classes. The first group is composed of the Alexandria, Dinophysis and Gymnodinum taxa. The second group includes the Pseudonitzschia taxon and the third group is Proocentrum. In addition, Figure 6(b), presents the results of the classification in the Moulay Bousselham site, this time, three groups are thus reformed, the first group is composed of the taxa Alexandrium, Gymnodinum and Dinophysis. A second group consisting of Proocentrum and a third group includes the Pseudonitzschia taxon.

The comparison of the abundance of these taxa in both sites confirms that the Moulay Bousselham site is characterized by the presence of genus with more toxic planktonic species represented mainly by Pseudonitzschia, in contrast to the Mehdia site known an abundance of the genus Proocentrum. This situation requires a more detailed study of the essential causes of the proliferation of these species.

\section{Conclusion}

There are five types of phytotoxins involved in human poisoning worldwide: • PSP or paralytic toxins $\bullet$ DSP or diarrheal toxins $\bullet$ NSP or neurotoxins $\bullet$ ASP or amnesic toxins - CFP or ciguatera toxins PSP toxins are the most common. The identification of the toxic species in the two Moroccan sites allowed us to mention five species known by their toxic power. Moreover, Dinophysis and Alexandrium are two planktonic taxa of which some species are capable of producing respectively diarrheal toxins and paralytic toxins. These two types of toxins accumulate in shells that feed on phytoplankton: this is the case of filtering shells 


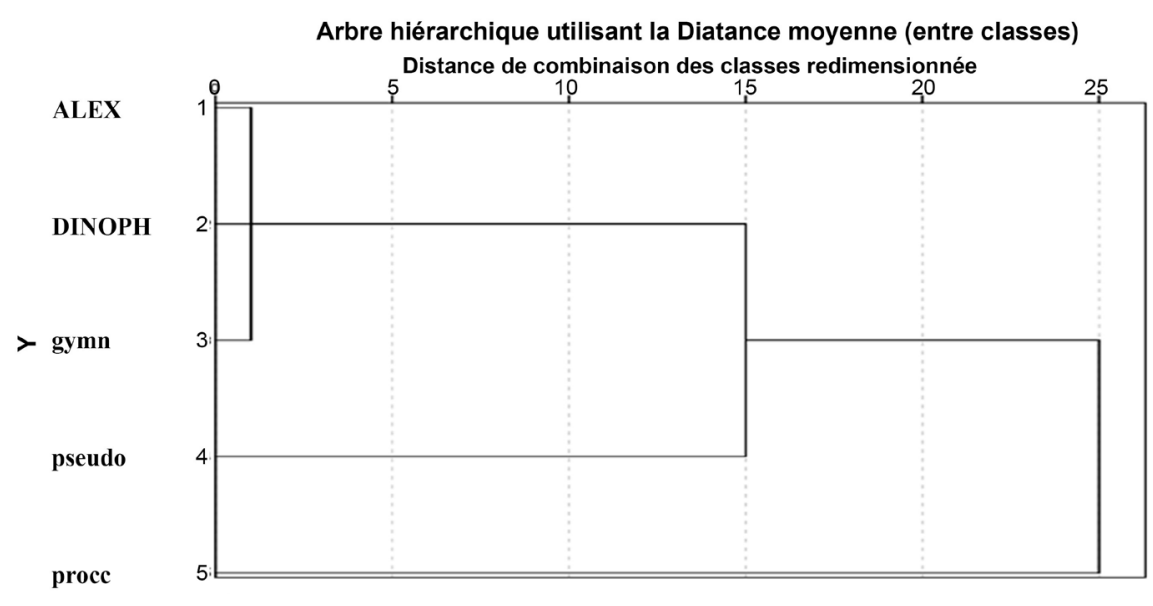

(a)

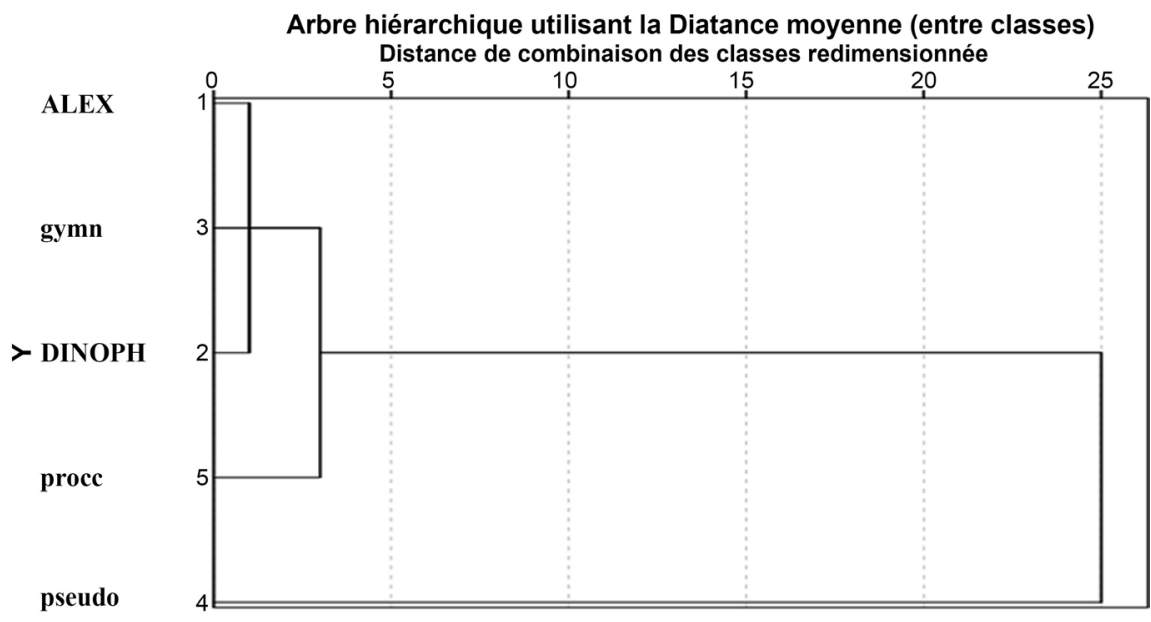

(b)

Figure 6. (a) Hierarchical presentation of planktonic taxa in the Mehdia site. ALEX: Alexandrium; DINOPH: Dinophysis; gymn: Gymnodinum; pseudo: Pseudonitzschia; procc: Proocentrum; (b) Hierarchical presentation of planktonic taxa in the Moulay boussel-ham site. ALEX: Alexandrium; DINOPH: Dinophysis; gymn: Gymnodinum; pseudo: Pseudonitzschia; procc: Proocentrum.

that become toxic to consumers, without being themselves affected. According to Lassus and Bardouil (1991); Marcaillou et al. (1990) [18] [19], the genus Dinophysis is widely represented in almost all the seas of the globe and in particular in coastal areas including the coasts of the Atlantic. Dinophysis produces diarrheal toxins, called DSP (Diarrheic Shellfish Poison) [20]. Another genus known by its toxic power that exists on the Moroccan coasts is Gymnodinum, which produces cytotoxic substances, hemolytic and aggressive for cell membranes [21]. However, the genus Proocentrum is not toxic to marine life, but some species of this genus may be toxic to the consumer. In fact, they produce ASP21 toxins or amnesic toxins, which can cause neurological disorders, including memory loss, in consumers of contaminated shellfish. The same assemblage of toxic planktonic species was found in a study conducted in Tunisia by Nejib et al. (2005) [22]. 


\section{Conflicts of Interest}

The authors declare no conflicts of interest regarding the publication of this paper.

\section{References}

[1] Bougis, P. (1974) Ecology of Marine Plankton. II Zooplankton. Masson et Cie.

[2] Dufour, P. and Durand, J.R. (1982) Plant Production in the Ivory Coast lagoons. Revista de Biología Tropical, 15, 209-230.

[3] Sialve, B. and Steyer, J.P. (2013) Microalgae, Promises and Challenges. Innovations Agronomiques, 26, 25-39.

[4] Cadoret, J.P., Bardor, M., Lerouge, P., Cabigliera, M., Henriquez, V. and Carlier, A. (2008) Microalgae Cellular Plants Producing Recombinant Commercial Molecules. Médecine/Sciences, 24, 375-382. https://doi.org/10.1051/medsci/2008244375

[5] Greenway, H. and Munns, R. (1980) Mechanisms of Salt Tolerance in No Halophytes. Annual Review of Plant Physiology, 31, 149-190. https://doi.org/10.1146/annurev.pp.31.060180.001053

[6] Dabbadie, L. (1992) Intensive Cultures of Microalgae on PIG Manure: Performance, Constraints, Use of Biomass. Diploma in Advanced Agronomy. National Agronomic School of Montpellier, France, 123 p.

[7] Netondo, G.W., Onyango, J.C. and Beck, E. (2004) Sorghum and Salinity: II. Gas Exchange and Chlorophyll Fluorescence of Sorghum under Salt Stress. Crop Science, 44, 806-811. https://doi.org/10.2135/cropsci2004.8060

[8] Perrine, Z., Negi, S. and Sayre, R.T. (2012) Optimization of Photosynthetic Light Energy Utilization by Microalgae. Algal Research, 1, 134-142.

https://doi.org/10.1016/j.algal.2012.07.002

[9] Dhargalkar, V.K. and Ingoleb, S. (2004) Phytoplankton Identification Manual. Ed National Institute of Oceanography, $2 \mathrm{p}$.

[10] Broutin, M., Caffier, G., Madi, M. and Artigas, L. (2011) Techniques for Monitoring the Abundance, Biomass and Diversity of Phytoplankton in Marine Waters. Ifremer, 2 .

[11] Sournia, A., Belin, C., Billard, C., Catherine, M., Erard-Le Denn, E., Fresnel, J., Lassus, P., Pastoureaud, A. and Soulard, R. (1992) The Repetitive and Expanding Occurrence of a Green Bloom-Forming Dinoflagellate (Dinophyceae) on the Coasts of France. Cryptogamie Algologie, 13, 1-13.

[12] le Grand, G. (1978) Dialogues. Volume I. Introduction, Bibliography and Maps by Adalbert de Vogué.

[13] Bourrelly, P. (1985) Freshwater Algae. Introduction to Systematics. Volume III: Blue and Red Algae. The Euglenians, Peridinians and Cryptomonadines. Paris, 606 p.

[14] Hall, S., Strichartz, G., Moczydlowski, E., Ravindran, A. and Reichardt, P.B. (1990) The Saxitoxins: Sources, Chemistry, and Pharmacology. In: Marine Toxins: Origin, Structure, and Molecular Pharmacology, American Chemical Society, New York, 29-65. https://doi.org/10.1021/bk-1990-0418.ch003

[15] Taylor, D.L. and Seliger, H.H. (1979) Toxic Dinoflagellate Blooms. Elsevier, North Holland, New York, 505.

[16] Anderson, D.M., White, A.W. and Baden, D.G. (1985) Toxic Dinoflagellates. Elsevier, New York, 561. 
[17] Graneli, E., Sundstrom, B., Edler, L. and Anderson, D.M. (1990) Toxic Marine Phytoplankton. Elsevier, New York, 554.

[18] Lassus, P. and Bardouil, M. (1991) Le Complexe "Dinophysis Acuminate": Identification of Species along the French Coast. Cryptogamie Algologie, 12, 1-9.

[19] Marcaillou-Le Baut, C., Bardin, B., Bardouil, M., Bohec, M., Le Déan, L., Masselin, P. and Truquet, P. (1990) Study of the Decontamination of Toxic Mussels (Diarrheal Toxins) in the Laboratory and in the Wild. Internal Report IFREMER/ DERO-90.02-MR, 21 p.

[20] UNESCO (1996) Design and Implementation of Some Harmful Algal Monitoring Systems. IOC Technical Series No. 44.

[21] Sournia, A., Belin, C., Berland, B., Erard-le den, E., Gentien, P., Grzebyk, D., Marcaillou-le Baut, C., Lassus, P. and Partensky, F. (1991) The Harmful Phytoplankton of the Coasts of France. From Biology to Prevention. IFREMER, S.D.P., 154 p.

[22] Nejib, M., Daly, Y., Souissi, S., Maamouri, F. and AISSAP (2005) Association Tintinnides (Ciliophora, Tintinnina) Dinoflagellés (Dinophyceae) Autotrophic Potentially Harmful at the Level of the Bay of Tunis, and Two Associated Lagoons: Ghar Elmelh and Tunis Sud. La mer, 43, 19-32. 